\title{
Variations in the number of active bacteria in the euphotic zone of a recently flooded reservoir
}

\author{
Louis B. Jugnia*, M. Richardot, D. Debroas, T. Sime-Ngando, J. Dévaux \\ Laboratoire de Biologie des Protistes, UMR-A CNRS 6023, Université Blaise Pascal (Clermont-Ferrand II), \\ 63177 Aubière cedex, France
}

\begin{abstract}
Using the CTC (5-cyano-2,3-ditolyl tetrazolium chloride) method, we estimated the active fraction of bacterioplankton in the euphotic zone of the recently flooded Sep Reservoir, France, with the aim of evaluating its importance and dynamics in relation to temperature and some components of dissolved organic matter (DOM) (i.e. dissolved combined amino acids: DCAA; dissolved free monosaccharides: $\mathrm{DFCHO}$; dissolved combined monosaccharides: DCCHO), and its metabolic significance in conjunction with a bacterial growth indicator: ${ }^{14} \mathrm{C}$-glucose uptake. From our results, it appears that only a small fraction (0.04 to $3.23 \%$ ) of total bacterial count in this reservoir was metabolically active. Recorded correlations and multivariate regression analysis suggest that temporal variations in the number of active bacteria are mainly $(80 \%)$ governed by temperature, together with the high concentrations of those components of DOM, which were present in this ecosystem but which apparently were not always available for bacterial metabolism. We also found a positive relation between the number of active bacteria and the potential heterotrophic activity, which suggest that CTC-positive bacteria are responsible for the bulk of bacterial community metabolism in this recently formed reservoir.
\end{abstract}

KEY WORDS: Active bacteria $\cdot$ CTC $\cdot$ Dissolved organic matter $\cdot$ Temperature $\cdot$ Bacterial activity New reservoir

\section{INTRODUCTION}

In aquatic microbial ecology, determining bacterial densities is usually the first stage in the process of studying relations between bacteria and biochemical processes such as the degradation and recycling of organic matter (e.g. Richardot et al. 2000). The most common method for counting planktonic bacteria is epifluorescence microscopy, which uses fluorescent stains (Hobbie et al. 1977, Porter \& Feig 1980) and provides an estimate of the total bacterial abundance in the environment, irrespective of their physiological state. It is now known that planktonic bacterial community consists of both metabolically active cells and of inactive cells (Dufour et al. 1990, Sommaruga \&

*E-mail: jugnia@caramail.com
Conde 1997). In most marine and lake ecosystems, it has been shown that the majority of bacterioplankton consist of cells that have a metabolic activity that is undetectable by the methods of autoradiographic labeling (Meyer-Reil 1978), flow cytometry (Jepras et al. 1995, Porter et al. 1995), or techniques using epifluorescence microscopy following specific cell staining (Zimmermann et al. 1978, Tabor \& Neihof 1984, Rodriguez et al. 1992) or cell treatment with nalidixic acid (Kogure et al. 1979). Nevertheless, the determination of the quantitative importance of the metabolically active fraction in the bacterioplankton and the factors that control its dynamics is of major interest since this fraction is the basis of bacterial population activity (Rodriguez et al. 1992).

Recent studies have suggested that variability in bacterioplankton species composition is one of the main factors regulating temporal variability of the active 
fraction of bacterioplankton (e.g. Thom et al. 1993), whereas others have suggested temperature (Tabor \& Neihof 1984, Robarts \& Sephton 1988, Sommaruga \& Conde 1997), lysis (Proctor \& Fuhrman 1990), grazing (Gasol et al. 1995) and resource availability (del Giorgio \& Scarborough 1995, Choi et al. 1999). In terms of resource availability, a wide variety of sources including phytoplankton excretion and lysis (Cole et al. 1988, Maurin et al. 1997) and grazing and release by zooplankton (e.g. Hygum et al. 1997) have been identified as producing dissolved organic matter (DOM) that fuels bacterioplankton metabolism. Inputs of allochthonous DOM and physical disaggregation of detrital particles (Hadas et al. 1990) are also likely to be significant energy sources for bacterial activities. However, nearly all these studies have been conducted in natural or stabilized artificial lake ecosystems. To our knowledge, no information is available on fluctuations in the number of active bacteria in recently flooded reservoirs that are expected to contain large quantities of terrestrial detritus and organic matter, which is known to efficiently regulate bacterial activity (Paterson et al. 1997).

The aim of this study was to determine the importance of the active fraction of bacterioplankton in a recently flooded reservoir, the main variables controlling their abundance (especially temperature and DOM) and their metabolic significance in conjunction with a growth indicator: ${ }^{14} \mathrm{C}$-glucose uptake. The numbers of active bacteria were determined by electron transport system (ETS) activity assays, based on reduction of the tetrazolium salt CTC (5-cyano-2,3-ditolyl tetrazolium chloride), which is currently the most widely used method in aquatic ecology (e.g. Sherr et al. 1999).

\section{MATERIALS AND METHODS}

Sites and sampling. The Sep Reservoir, situated at an altitude of $500 \mathrm{~m}$ in the French Massif Central $\left(46^{\circ} 2^{\prime} \mathrm{N}, 3^{\circ} 1^{\prime} \mathrm{E}\right)$, was built in 1994 by damming the Sep and Riaux streams. With an area of 33 ha and a mean depth of $14 \mathrm{~m}$, this reservoir has a catchment of $27 \mathrm{~km}^{2}$ whose vegetation consists of oak and beech forests and grasslands. The reservoir, which is oligomesotrophic in status, was completely filled for the first time in January 1995 and its mean residence time is 220 d. Temporal changes since flooding have shown evidence for a decrease in the proportion of heterotrophic and mixotrophic organisms in the planktonic biomass, these being progressively replaced by strictly autotrophs (Thouvenot et al. 2000).

Sampling was carried out at a permanent station situated at the deepest zone of the reservoir near the dam. Water samples from $1 \mathrm{~m}$ below the surface were collected every 2 wk in April and weekly from May to August 1997 with a Van Dorn water sampler.

Physico-chemical parameters. Temperature and dissolved oxygen were measured in situ with a YSIGRANT/3000 multiparametric probe. Chemical analyses, namely ammonium $\left(\mathrm{NH}_{3}-\mathrm{N}\right)$, nitrates $\left(\mathrm{NO}_{3}-\mathrm{N}\right)$, and orthophosphate $\left(\mathrm{PO}_{4}-\mathrm{P}\right)$, were performed using standard methods (APHA 1992).

Duplicate DOM determinations were conducted. Water samples prefiltered through prewashed $0.2 \mu \mathrm{m}$ pore size polycarbonate filters were used to determine the DOM content. Dissolved combined amino acids (DCAA) were determined by the 'micro BCA Protein Assay Reagent' Kit (Pierce). Bovine serum albumin (BSA) was used as a standard. Dissolved free amino acid (DFAA) analyses were performed with the $o$ phthalaldehyde method, as described by Parsons et al. (1984), using glycine as a standard. The coefficients of variation for the TDAA (total dissolved amino acids, DCAA and DFAA) analysis varied between 0.6 and $6.0 \%$. Dissolved free monosaccharides (DFCHO) were determined according to Burney \& Sieburth (1977) and Johnson \& Sieburth (1977), using glucose as a standard. Total dissolved carbohydrate (TDCHO) concentrations were determined after hydrolysis with $\mathrm{HCl}(1 \mathrm{~N}$; $\left.100^{\circ} \mathrm{C}, 15 \mathrm{~h}\right)$. TDCHO minus DFCHO gave dissolved combined carbohydrates (DCCHO) (the coefficients of variation for the DCCHO analysis varied between 0.7 and $7.0 \%$ ). The amount of organic carbon stemming from the protein and carbohydrate pool (C-TDAA + $\mathrm{C}$-TDCHO) was calculated assuming that $1 \mathrm{mg}$ of glucose is equivalent to $0.4 \mathrm{mg}$ carbon, and $1 \mathrm{mg}$ of BSA and glycine are equivalent to 0.5 and $0.16 \mathrm{mg}$ carbon, respectively.

Biological variables. Total counts of bacterial cells were obtained from aliquots of subsamples fixed with formalin at a final concentration of $2 \%$, after staining with DAPI (Porter \& Feig 1980) and counting under epifluorescence microscopy. At least 500 bacterial cells were counted and measured in 20 to 50 fields of view of the microscope. The length and width of bacterial cells were estimated using an eyepiece micrometer. The number of respiring bacteria cells was determined by counting those showing an ETS activity (Zimmermann et al. 1978) using the procedure described by Rodriguez et al. (1992). Briefly, $0.5 \mathrm{ml}$ of CTC stock solution was added to freshly collected water $(10 \mathrm{ml})$. In a preliminary test, a final concentration of $0.75 \mathrm{mM}$ was found to be sufficient to detect respiring bacteria. This concentration is within values used for pelagic systems (del Giorgio et al. 1997, Choi et al. 1999) and, according to Sherr et al. (1999), lower than the value (10 mM) above which the number of stained cells also tends to decline, presumably due to toxicity of CTC or its formazan products (Choi et al. 1999). The mixture 
was incubated at room temperature $\left(18^{\circ} \mathrm{C}\right)$ for about $2 \mathrm{~h}$. Thereafter, the sample was filtered through a black nuclepore polycarbonate membrane (pore size, $0.2 \mu \mathrm{m}$ ), air dried and respirometrically active cells were counted microscopically. Our incubation time was chosen from preliminary tests and was within the shorter time period of incubation reported by many authors (Rodriguez et al. 1992, Choi et al. 1996, Lovejoy et al. 1996). Moreover, our incubation method, which consisted of small aliquots of liquid samples incubated with the CTC, seems more accurate according to Sherr et al. (1999). Indeed, it provides good results compared to the membrane incubation method of Karner \& Furhman (1997) in which a large volume $(\sim 30 \mathrm{ml})$ of water is settled onto membrane filters, the filter surface is flooded with CTC solution, and the filter is incubated for a period of time.

Experiments on heterotrophic activity of microbial assemblages were run every $2 \mathrm{wk}$ and estimated using $\left[\mathrm{U}-{ }^{14} \mathrm{C}\right]$ glucose (specific activity $=293 \mathrm{mCi} \mathrm{mmol}^{-1}$;
Amersham). At the sampled depth, serial increasing concentrations ranging from 0.5 to $2.7 \mu \mathrm{g} \mathrm{Cl}^{-1}$ of the labeled tracer were added to duplicate subsamples $(30 \mathrm{ml})$ and 1 formalin-killed control and incubated in situ and in the dark for $3 \mathrm{~h}$. Thereafter, particles were retained on $0.2 \mu \mathrm{m}$ Sartorius filters, rinsed twice with $5 \mathrm{ml}$ of deionized water, and the filters were stored in a scintillation cocktail. Radioactivity was counted with a $\mathrm{LKB}^{\circledR}$ counter. The maximum rates of substrate uptake $\left(V_{\max }\right)$, considered as the potential heterotrophic activity (PHA), were calculated using Michaelis-Menten kinetics and the Lineweaver Burke transformation (Wright \& Hobbie 1965).

Statistical treatments mainly consisted of linear pairwise correlation analysis to establish the relationship between bacterial variables and environmental parameters. In addition, step-wise multiple regressions (with forward selection) were used to relate bacterial variables with the physical environment (i.e. temperature) and resource factors (i.e. DOM).
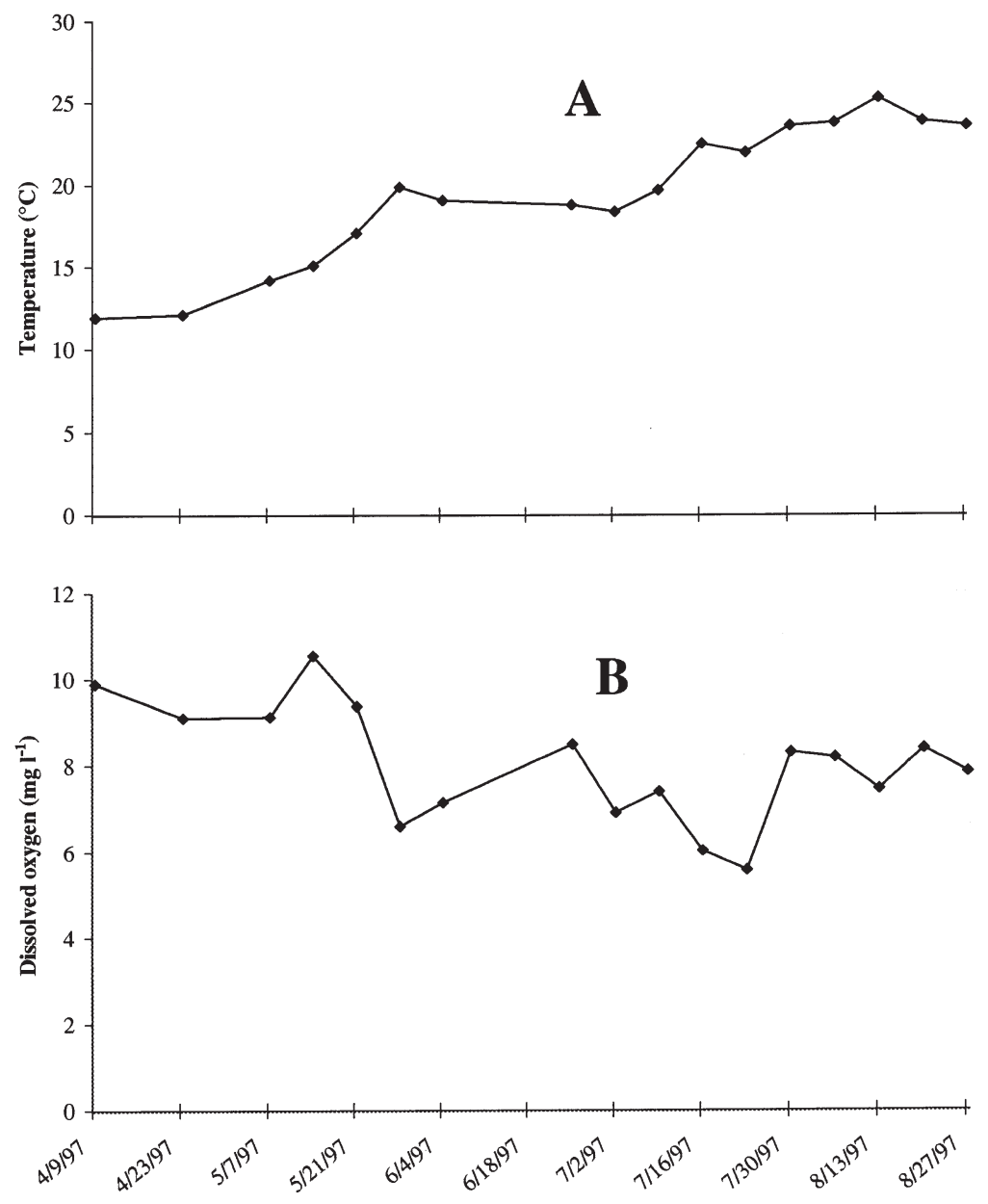

Fig. 1. Temporal variations of (A) temperature and (B) dissolved oxygen in the euphotic zone of Sep Reservoir, France. Dates given as mo/d/yr

\section{RESULTS}

The temperature at our sampling depth increased throughout the study, from $<12$ to $\sim 26^{\circ} \mathrm{C}$ (Fig. 1A). Dissolved oxygen values changed slightly over the sampling time (Fig. 1B), the mean $( \pm \mathrm{SD})$ value being $8.03 \pm 1.3 \mathrm{mg} \mathrm{l}^{-1}$ (range $=5.58$ to $10.55 \mathrm{mg} \mathrm{l}^{-1}$ ). The mean concentrations of nitrates, ammonium and orthophosphate were $1.59 \mathrm{mg} \mathrm{N}^{-1}$ (0.87 to $2.3 \mathrm{mg} \mathrm{N}$ $\mathrm{l}^{-1}$ ), $0.006 \mathrm{mg} \mathrm{N}^{-1}$ (0.003 to $0.009 \mathrm{mg} \mathrm{N} \mathrm{l}^{-1}$ ) and $0.030 \mathrm{mg} \mathrm{P} \mathrm{l}^{-1}$ (0.015 to $0.047 \mathrm{mg} \mathrm{P} \mathrm{l}^{-1}$ ), respectively.

The values of DFCHO varied about 7 -fold, from 0.31 to $2.27 \mathrm{mg} \mathrm{l}^{-1}$, whereas DCCHO varied about 40-fold, between 0.05 and $2.12 \mathrm{mg} \mathrm{l}^{-1}$. For these 2 variables, the mean values were $1.08 \pm 0.55$ and $0.92 \pm 0.54 \mathrm{mg} \mathrm{l}^{-1}$, respectively. Temporal variations in the concentrations of DCCHO and DFCHO did not show a regular trend during the study. However, except for the period from late May to mid-June, late July and mid-August, when there was a clear positive correlation between the concentrations of DCCHO and DFCHO, they were mostly negatively correlated (Fig. 2A). Temporal changes in DCAA concentrations could be divided into 2 distinct periods. In the first phase, the DCAA concentrations varied between 4.1 and $5.2 \mathrm{mg} \mathrm{l}^{-1}$. From 18 June onward, there was a quick change to higher concentrations, which reached peak values at the end of sampling (Fig. 2B). The mean DFAA content was $1.8 \pm 1.0 \mathrm{mg} \mathrm{l}^{-1}$. 
Two periods of high concentrations were recorded, at the end of May and end of August, when the concentrations peaked at 3.7 and $4.2 \mathrm{mg} \mathrm{l}^{-1}$, respectively (Fig. 2B). The amount of organic carbon derived from DOM made up of protein and carbohydrate pools fluc- tuated between $2.9 \mathrm{mg} \mathrm{C}^{-1}$ and $5.3 \mathrm{mg} \mathrm{C}^{-1}$ with a mean value of $4.1 \mathrm{mg} \mathrm{C}^{-1}$. Seasonally, their concentrations were about $3.0 \mathrm{mg} \mathrm{C}^{-1}$ during the first 3 sampling dates of the study; thereafter, they increased steadily

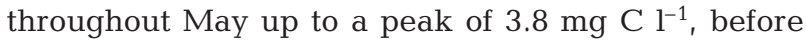
declining to a constant value during June. From 9 July, the organic carbon concentrations increased strongly and reached the highest values measured during this study (Fig. 2B).

The bacterial population mostly consisted of free-living cells with a mean biovolume of $0.06 \mu^{3}$. The density of CTC-positive bacteria fluctuated by about 2 orders of magnitude, from 0.10 to $10.20 \times 10^{4}$ cells ml $^{-1}$ (mean $=4.12 \pm$ $3.39 \times 10^{4}$ cells ml ${ }^{-1}$ ), whereas the density of total bacteria varied only between 1.41 and $4.49 \times 10^{6}$ cells ml $\mathrm{ml}^{-1}$ $\left(\right.$ mean $=2.93 \pm 0.83 \times 10^{6}$ cells ml $\left.{ }^{-1}\right)$ (Fig. 2C). The abundance of bacteria counted using DAPI was highest at the start of the study, on 18 June and 13 August. The dynamics of CTC-active bacteria can be separated into 3 distinct periods. From the start of the study to 21 May, they were particularly infrequent $($ mean $=2.55 \pm 1.16 \times$ $10^{4}$ cells $\mathrm{ml}^{-1}$ ); their number increased from the end of May and fluctuated between 2.3 and $3.1 \times 10^{4}$ cells $\mathrm{ml}^{-1}$. From 9 July, the abundance of CTCactive bacteria increased strongly and reached the highest values measured during this study (Fig. 2C). Active bacteria accounted for between 0.04 and $3.22 \%$ of total bacterial abundance and their seasonal variation was apparently independent of that of total bacterial abundance. The values of ${ }^{14} \mathrm{C}$-glucose uptake fluctuated be-

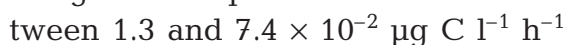
$\left(\right.$ mean $\left.=3.0 \pm 1.8 \times 10^{-2} \mu \mathrm{g} \mathrm{C} \mathrm{l}^{-1} \mathrm{~h}^{-1}\right)$, the highest values being recorded in summer (Fig. 2A).

The abundance of CTC-positive bacteria was significantly correlated with the water temperature (Table 1). Bacterial uptake of ${ }^{14} \mathrm{C}$-glucose plus the DOM contents (DFAA, DCAA and TDCHO) were better correlated with the number of metabolically active bacteria than with total abundance (Table 1). The multiple regression analysis suggested that $80 \%$ of the
Fig. 2. Temporal variations of (A) dissolved free carbohydrate (DFCHO), dissolved combined carbohydrate (DCCHO) and ${ }^{14} \mathrm{C}$-glucose uptake rates (PHA: potential heterotrophic activity), (B) dissolved combined amino acids (DCAA), dissolved free amino acids (DFAA) and carbon content (from C-TDAA + C-TDCHO), (C) bacterial abundance and active bacteria (CTC-reducing bacteria), in the euphotic zone of Sep Reservoir. Dates given as mo/d/yr 
Table 1. Variables that showed significant correlation with CTC-positive bacteria ( $\mathrm{n}=$ number of samples)

\begin{tabular}{|lccc|}
\hline \multicolumn{2}{l}{ Coefficient correlation } & $\mathrm{p}$ & $\mathrm{n}$ \\
\hline Temperature & 0.9 & $<0.001$ & 17 \\
& & & \\
$V_{\max }$ of glucose uptake & 0.6 & $<0.01$ & 9 \\
& & & \\
C (TDAA+TDCHO) & 0.9 & $<0.001$ & 17 \\
DFAA & 0.5 & $<0.05$ & 17 \\
DCAA & 0.8 & $<0.05$ & 17 \\
\hline
\end{tabular}

total variance observed in the number of CTC-positive bacteria could be explained by the temperature and the availability of resources, and particularly the quantity of DOM. When considered separately, the temperature and DOM explained 66 and $75 \%$ of the variance in abundance of CTC-positive bacteria, respectively.

\section{DISCUSSION}

\section{Methodological aspects and quantitative importance of CTC-positive cells}

Despite the multitude of known methods used for distinguishing active bacteria from non-active ones within the bacterial community, none provide unambiguous counts of active bacteria in the water, the results even sometimes being contradictory. For example, Maki \& Remsen (1981) concluded that counts of active bacteria by methods using the tetrazolium salt INT (2-p-iodophenyl-3p-nitrophenyl-5-phenyl tetrazolium chloride) or using nalidixic acid gave identical results, whereas Tabor \& Neihof (1984) showed that, in general, the nalidixic acid method overestimated the density of active cells compared to an autoradiographic method and that using INT. Such divergences suggest prudence when comparing the results of studies relating to the number of active bacterial cells in various environments obtained using different methods. The method of estimation by autoradiography of active bacteria requires long incubation times and high concentrations of labeled nutrients, whereas with the nalidixic acid method, the problem is mainly distinguishing those cells that have actually increased in size after incubation. Methods using tetrazolium salts (formazan-positive) are easy to use (Zimmerman et al. 1978, Maki \& Remsen 1981, Tabor \& Neihof 1984, Rodriguez et al. 1992) and do not have the disadvantages mentioned above. There are however some methodological biases associated with these tetrazolium salt methods which can lead to an underestimate of the percentage of active bacteria. These are: (1) undetectable spots of formazan formed inside small-sized cells,
(2) the presence of cells with a low DNA content, which according to Choi et al. (1996) are less sensitive to CTC, (3) an overestimate of total bacterial abundance after staining with DAPI with notably the inclusion of some large DNA viruses (Sommaruga et al. 1995) and of 'ghost cells' (in the sense of Zweifel \& Hagström 1995). In this study, the number of active bacteria was determined using the tetrazolium salt method, in particular the CTC method described by Rodriguez et al. (1992) because: (1) methods that use tetrazolium salts are easily applicable for routine purposes (Dufour \& Colon 1992), (2) among the tetrazolium salts, INT is less directly coupled to respiratory activity than is the reduction of CTC (Smith \& McFeters 1997), (3) CTC is currently the most widely used tetrazolium salt in studies of aquatic environments (Gasol et al. 1995, Choi et al. 1996, Lovejoy et al. 1996, Karner \& Fuhrman 1997, Choi et al. 1999, Pinhassi et al. 1999, Sherr et al. 1999).

During this study, the number of CTC-positive bacteria in the surface waters of the Sep Reservoir varied from 0.10 to $10.20 \times 10^{4}$ cells $\mathrm{ml}^{-1}$, corresponding to $0.04-3.22 \%$ of the total bacterial density. Setting aside methodological differences, our results, like those of many other authors (Dufour et al. 1990, del Giorgio \& Scarborough 1995, Sommaruga \& Conde 1997), show that not all bacteria are metabolically active. In terms of the percentage of CTC-positive bacteria, our values are at the lower end of those reported in other studies (Table 2); they are similar to those reported by Rao et al. (1981) in Canadian lakes and by Lovejoy et al. (1996) in the Gulf of St. Lawrence (Canada). Relatively low values have also been reported from the Baltic Sea (Zimmermann et al. 1978) and Blanes Bay, USA (Gasol et al. 1995).

In general, in all instances where CTC has been used in natural water samples, the proportion of active cells has been low, typically between $<1$ and $35 \%$ (del Giorgio \& Scarborough 1995, Choi et al. 1996, del Giorgio et al. 1996, 1997, Lovejoy et al. 1996, this study). This does not imply the failure of CTC to detect all cells that are metabolically active in the plankton, but the result of the CTC reduction assay should be viewed and interpreted as identifying the most highly active cells in bacterioplankton populations or assemblages (Sherr et al. 1999). Indeed, the level of cell activity is what determines the detectability of respiring cells, since even bacteria in a starvation survival state must sustain certain functions, such as maintenance of the cell membrane integrity and active transport systems, and can carry out a low level of protein synthesis (Sherr et al. 1999). Choi et al. $(1996,1999)$ have shown that a portion, and sometimes a large fraction, of supposedly inactive bacteria cells can be induced to high metabolic activity by a change in environmental conditions (e.g. substrate availability, temperature increase). 
Table 2. Range or mean values for percent of active bacteria in different water bodies using different methods

\begin{tabular}{|lcll|}
\hline Location & \% active cells & Method & Source \\
\hline Westensee lake (Germany) & $23-36$ & INT reduction method & Zimmermann et al. (1978) \\
Baltic sea (Kiel Firth, Germany) & 12 & INT reduction method & Zimmermann et al. (1978) \\
Baltic sea (Kiel Bight, Germany) & 7 & INT reduction method & Zimmermann et al. (1978) \\
Lake Huron (Canada) & $0.5-3.2$ & INT reduction method & Rao et al. (1981) \\
Georgian parc (Canada) & $1.2-5.7$ & INT reduction method & Rao et al. (1981) \\
Erié Lake (Canada) & $3.9-7.2$ & INT reduction method & Rao et al. (1981) \\
Lake St-George (Canada) & $3.4-3.5$ & INT reduction method & Rao et al. (1981) \\
Chesapeake Bay (MD, USA) & $25-94$ & INT reduction method & Tabor \& Neihof (1984) \\
Hartbeespoort Reservoir (South Africa) & $16.4-20.4$ & Nalidixic acid method & Robarts \& Sephton (1988) \\
Lake Geneva (France) & $1-47$ & INT reduction method & Dufour et al. (1990) \\
Fish Pond (Ivory Coast) & $28-71$ & INT reduction method & Dufour et al. (1990) \\
24 Canadian lakes (Canada) & $15-33$ & CTC reduction method & del Giorgio \& Scarborough (1995) \\
Blanes Bay (MD, USA) & 6.4 & CTC reduction method & Gasol et al. (1995) \\
14 Canadian lakes (Canada) & $7.8-47.1$ & CTC reduction method & del Giorgio et al. (1996) \\
Gulf of St. Lawrence (Canada) & $<1-2$ & CTC reduction method & Lovejoy et al. (1996) \\
Lake Rodo (Uruguay) & $17-100$ & INT reduction method & Sommaruga \& Conde (1997) \\
Sep Reservoir & $0.04-3.23$ & CTC reduction method & This study \\
\hline
\end{tabular}

The creation of a new reservoir and flooding of a lake may initiate a series of changes in the plankton community related to alterations in hydrology and nutrient availability that frequently result from inputs of large amounts of newly flooded terrestrial organic matter that may also stimulate bacterial activity (Paterson et al. 1997). These effects almost always lead to the ecosystem evolving toward a new steady state of maturation with a trophic status generally lower than that observed immediately after flooding, and that may be achieved within years (Robarts et al. 1992, Paterson et al. 1997). It has been established over a broad range of aquatic systems that the number of active bacteria increases with the system's productivity (del Giogio \& Scarborough 1995). Indeed, according to those authors who have also used the CTC method during their investigation, the proportion of active cells may increase from values typical of ultra-oligotrophic openocean areas $(<5 \%)$ to highly productive estuaries (>50\%). The study of the temporal changes in the Sep Reservoir showed, firstly, a lowering in the DOM concentration with time (Richardot et al. 2000) and, secondly, a decrease in the proportion of heterotrophic organisms, such as bacteria, and mixotrophic organisms, which were progressively replaced by strictly autotrophic organisms (Thouvenot et al. 2000). The low number of CTC-active bacteria determined at this site during our study could in part be related to changes in this ecosystem.

\section{Relations with the other parameters measured}

As in other studies (Tabor \& Neihof 1984, Robarts \& Sephton 1988, Sommaruga \& Conde 1997), the water temperature in the Sep Reservoir was significantly correlated with the number of metabolically active bacteria (Table 1). In the surface waters of the Gulf of St. Lawrence in Canada, the low proportions of CTC-active bacteria observed by Lovejoy et al. (1996) were between 1 and $2 \%$ during summer stratification and fell to $<1 \%$ in winter. This was the same case in the Sep Reservoir, where active bacteria accounted for between 0.04 and $3.22 \%$ of total abundance but had apparently higher densities during the period of thermal stratification (Fig. 2C). Similarly, in a comparative review of published data, Sommaruga \& Conde (1997) concluded that in conditions where resources are not limiting, warming the water leads to an increase in the abundance of metabolically active bacteria. For example, in Lake Rodo (Uruguay), those authors calculated that the numbers of CTC-positive bacteria were increased by more than an order of magnitude, parallel to an increase in temperature from 8 to $28^{\circ} \mathrm{C}$. During this study, the water temperature at our sampling depth varied from $<12$ to $\sim 26^{\circ} \mathrm{C}$, leading to a $\sim 100$-fold increase in the abundance of CTC-positive bacteria. This observation agrees with that of Sommaruga \& Conde (1997), and also puts the temperature dependence of our results in line with other recent reports 
showing strong temperature dependence of bacterial growth rates at environmental temperatures of less than $20^{\circ} \mathrm{C}$ (e.g. Kirchman \& Rich 1997). Thus, temperature appears to have had a profound effect on the pattern of induction of high ETS activity and of increased growth yields in the bacterial cells of our ecosystem.

The multiple regression analysis showed that $80 \%$ of the total variance associated with the numbers of CTCpositive bacteria could be explained by temperature and DOM and the correlation with the dissolved organic carbon stemming from the protein and carbohydrate pool (Table 1) show that, in this ecosystem, temperature is not the only factor involved in controlling the abundance of CTC-positive bacteria. Moreover, as in numerous studies that have already reported a good relation between metabolically active bacteria and bacterial activities, particularly bacterial ${ }^{14}$ C-glucose uptake (Robarts \& Sephton 1988, Dufour et al. 1990), we also showed, in this study, a relation between active bacteria and the uptake of a directly usable component, namely glucose. Such a relation suggests that CTC-positive bacteria are responsible for the bulk of bacterial community metabolism in this recently formed reservoir. The statistical dependence between CTC-positive bacteria and DOM could have been caused solely by the increase in temperature, which appears to be the main factor explaining the fluctuations in the number of CTC-active bacteria, and which is also usually the controlling factor in the phenomena involved in the production of autochthonous organic matter readily assimilable by bacteria. Nevertheless, since the concentrations of TDAA and TDCHO in this reservoir were within the higher range measured in many ecosystems (Striquer-Soares \& Chevolot 1996), the significant relationship between CTC-positive bacteria and supposedly readily useable DOM seems surprising. In fact, the high amount of organic matter present in this recently flooded reservoir was not from autochthonous production, but was mainly of allochthonous origin and difficult to biodegrade (Richardot et al. 2000). So, it is possible that, at times, the bio-availability of these compounds could also have been a limiting factor for the development of bacterioplankton. A previous study showed that DFAA and DCAA may contribute substantially to bacterial growth (Simon \& Rosenstock 1992), and Choi et al. (1999) recorded a large increase in the percentage of CTC-positive bacteria with the addition of mixed amino acids. Moreover, Rosenstock \& Simon (1993) reported an increased use of DCAA by bacterioplankton, when these components were resistant to the microbial degradation. Results from our observations demonstrate the role of organic matter and its assimilation in the regulation of the temporal variability in the number of active bacteria in the Sep Reservoir, and particularly
TDAA since statistical relations were more significant with DFAA and DCAA (Table 1).

To our knowledge, the significant relationship we recorded between organic matter and metabolically active bacteria is the first one in a recently flooded reservoir. In old and stabilized ecosystems, contrasting relationships between organic matter and metabolically active bacteria have been reported. Kogure et al. (1980) concluded from their survey of metabolically active bacteria in the water around Japan that the numbers increased in relation to the particulate and dissolved organic carbon concentrations. In Hartbeespoort Dam, Robarts \& Sephton (1988) did not observe any correlation between the number of metabolically active bacteria and the dissolved organic carbon concentration. However, few in situ simultaneous estimates of DOM concentrations and active bacteria are sufficiently complete to permit accurate comparisons. The relation we observed between DOM and active bacteria agrees with recent reports by Pinhassi et al. (1999) and Choi et al. (1999), who recorded an increase in the number of viable bacteria (using the CTC method) in experimental mesocosms incubated at 15 and $20^{\circ} \mathrm{C}$, respectively, and amended with organic substrates (i.e. amino acids, protein and carbohydrates).

From our results it appears that only a small fraction ( 0.04 to $3.23 \%$ ) of the total bacterial count in the Sep Reservoir was metabolically active. Based on a recent study published by Choi et al. (1999), this fraction may be considered to be formed by bacterial cells with a high ETS activity since many more cells apparently become CTC-positive over time with the increase in temperature, and the high PHA during summer depended on the high DOM concentrations recorded in the water. These high DOM concentrations were probably linked with the recently flooded character of the reservoir. Other studies have demonstrated that bacterivorous protists graze preferentially on larger bacterial cells (Gonzalez et al. 1990), dividing cells (Sherr et al. 1992), and CTC-positive bacteria (del Giorgio et al. 1996). Thus, the action of those micro-organisms is likely to also control the abundance of CTC-positive bacteria and needs to be investigated in the future.

Acknowledgements. We gratefully acknowledge financial support from the European Community and from the following French national and regional organizations: 'Ministère de l'Environnement', 'Agence de l'eau Loire-Bretagne', Conseil Régional d'Auvergne', 'Conseil Général du Puy-de-Dôme', and 'Syndicat des Agriculteurs Irrigants de la Haute Morge'. We also thank the numerous people who were conscripted as field assistants during this study, namely C. Mallet, J.-C. Romagoux, D. Sargos, R. D. Tadonléké and A. Thouvenot. We are also grateful for the valuable comments and suggestions on an earlier version of the manuscript by 2 anonymous reviewers. This is a contribution to the SEP Project and to the CNRS UMR 6023 (Biologie des Protistes) research programs. 


\section{LITERATURE CITED}

APHA (American Public Health Association) (1992) Standard methods for examination of water and wastewater, 18th ed. APHA, Washington, DC

Burney CM, Sieburth JMcN (1977) Dissolved carbohydrates in seawater. II. A spectrophotometric procedure for total carbohydrate analysis and polysaccharide estimation. Mar Chem 5:15-28

Choi JW, Sherr EB, Sherr BF (1996) Relation between presence absence of a visible nucleoid and metabolic activity in bacterioplankton cells. Limnol Oceanogr 41:1169-1179

Choi WJ, Sherr BF, Sherr EB (1999) Dead or alive? A large fraction of ETC-inactive marine bacterioplankton cells, as assessed by reduction of CTC, can become ETS-active with incubation and substrate addition. Aquat Microb Ecol 18:105-115

Cole JJ, Findlay S, Pace ML (1988) Bacterial production in fresh and saltwater ecosystems: a cross-system overview. Mar Ecol Prog Ser 43:1-10

del Giorgio PA, Scarborough G (1995) Increase in the proportion of metabolically active bacteria along gradient of enrichment in freshwater and marine plankton: implication for estimates of bacteria growth and production rates. J Plankton Res 17:1905-1924

del Giorgio PA, Gasol JM, Mura P, Vaque D, Duarte CM (1996) Bacterioplankton community structure regulation: protists control net production and the proportion of active bacteria in a coastal marine community. Limnol Oceanogr 41:1169-1179

del Giorgio PA, Prairie YT, Bird DF (1997) Coupling between rates of bacterial production and the abundance of metabolically active bacteria in lakes, enumerated using CTC reduction and flow cytometry. Microb Ecol 34:144-154

Dufour P, Colon M (1992) The tetrazolium reduction method for assessing the viability of individual bacteria cells in aquatic environments: improvements, performance and applications. Hydrobiologia 232:211-218

Dufour P, Torreton JP, Colon M (1990) Advantages of distinguishing the active fraction in bacterioplankton assemblages: some examples. Hydrobiologia 207:295-301

Gasol JM, Del Giorgio PA, Massana R, Duarte CM (1995) Active versus inactive bacteria: size dependence in a coastal marine plankton community. Mar Ecol Prog Ser 128:91-97

Gonzalez JM, Sherr EB, Sherr BF (1990) Size selective grazing on bacteria by natural assemblages of estuarine flagellates and ciliates. Appl Environ Microbiol 56:583-589

Hadas O, Pinkas R, Abert-Diez C, Bloem J, Cappenberg T, Berman $T$ (1990) The effect of detrital addition on the development of nanoflagellates and bacteria in lake Kinneret. J Plankton Res 12:185-199

Hobbie JE, Daley RJ, Jasper S (1977) Use of nuclepore filter for counting bacteria by fluorescence microscopy. Appl Environ Microbiol 33:1225-1228

Hygum BH, Petersen JW, Sondergaard M (1997) Dissolved organic carbon released by zooplankton grazing activity - a high quality substrate pool for bacterial. J Plankton Res 19:97-111

Jepras RJ, Carter J, Pearson SC, Paul FE, Wilkinson MJ (1995) Development of a robust flow cytometric assay for determining number of viable bacteria. Appl Environ Microbiol 61:2696-2701

Johnson KM, Sieburth JMcN (1977) Dissolved carbohydrates in seawater. I. A precise spectrophotometric analysis for monosaccharides. Mar Chem 5:1-13

Karner M, Fuhrman JA (1997) Determination of active marine bacterioplankton: a comparison of universal 16S rRNA probes, autoradiography, and nucleoid staining. Appl Environ Microbiol 63:1208-1213

Kirchman DL, Rich JH (1997) Regulation of bacterial growth rates by dissolved organic carbon and temperature in the Equatorial Pacific Ocean. Microb Ecol 33:11-20

Kogure K, Simidu U, Taga N (1979) A tentative direct method for counting living marine bacteria. Can J Microbiol 25: $415-420$

Kogure K, Simidu U, Taga N (1980) Distribution of viable marine bacteria in neretic seawater around Japan. Can J Microbiol 26:318-323

Lovejoy C, Legendre L, Klein B, Tremblay JE, Ingram RG, Therriault JC (1996) Bacterial activity during early winter mixing (Gulf of St. Lawrence, Canada). Aquat Microb Ecol 10:1-13

Maki JS, Remsen CC (1981) Comparison of two direct count methods for determining metabolizing bacteria in freshwater. Appl Environ Microbiol 41:1132-1138

Maurin N, Amblard C, Bourdier G (1997) Phytoplankton excretion and bacterial reassimilation in an oligomesotrophic lake: molecular weight fractionation. J Plankton Res 19:1045-1068

Meyer-Reil LA (1978) Autoradiography and epifluorescence microscopy combined for the determination of number and spectrum of actively metabolizing bacteria in natural waters. Appl Environ Microbiol 36:506-512

Parsons TR, Maita Y, Lalli C (1984) A manual of chemical and biochemical methods for seawater analysis. Pergamon Press, Oxford

Paterson MJ, Findlay D, Betty K, Findlay W, Schindler EU, Stainton M, McCullogh G (1997) Change in the planktonic food web of a new experimental reservoir. Can J Fish Aquat Sci 54:1088-1102

Pinhassi J, Azam F, Hemphala J, Long RA, Martinez J, Zweifel UL, Hagström $\AA$ (1999) Coupling between bacterioplankton species composition, population dynamics, and organic matter degradation. Aquat Microb Ecol 17: $13-26$

Porter J, Diaper J, Edwards C, Pickup R (1995) Direct measurements of natural planktonic bacterial community viability by flow cytometry. Appl Environ Microbiol 61: 2783-2786

Porter KG, Feig YS (1980) The use of DAPI for identifying and counting aquatic microflora. Limnol Oceanogr 25:943-948

Proctor LM, Fuhrman JA (1990) Viral mortality of marine bacteria and cyanobacteria. Nature (London) 343:60-62

Rao SS, Jurkovic AA, Dutka BJ (1981) Application de la technique de reduction du int-formazan et de l'orange d'acridine à l'estimation de l'activité bactérienne en eau douce. Eau Que 14:234-236

Richardot M, Debroas D, Jugnia LB, Tadonléké R, Berthon L, Dévaux J (2000) Changes in bacterial processing and composition of dissolved organic matter in a newly-flooded reservoir (a three-year study). Arch Hydrobiol 148: 231-248

Robarts RD, Sephton LM (1988) Seasonal variation of metabolically active bacteria in a hypertrophic lake (Hartbeespoort Dam, South Africa). Hydrobiologia 160:179-188

Robarts, RD, Zohary T, Jarvis AC, Pais-Mandeira CM, Sephton LM, Combrink S (1992) Phytoplankton and zooplankton population dynamics and production of a recently formed African reservoir. Hydrobiologia 237:47-60

Rodriguez GG, Phipps D, Ishiguro K, Ridgway HF (1992) Use of fluorescent redox probe for direct visualization of actively respiring bacteria. Appl Environ Microbiol 58: 1801-1808 
Rosenstock B, Simon M (1993) Use of dissolved combined and free amino acids by planktonic bacteria in Lake Constance. Limnol Oceanogr 38:1521-1531

Sherr BF, Sherr EB, McDaniel J (1992) Effect of protistan grazing on the frequency of dividing cells in bacterioplankton assemblages. Appl Environ Microbiol 58:2381-2385

Sherr BF, del Giorgio P, Sherr EB (1999) Estimating abundance and single-cell characteristics of respiring bacteria via the redox dye CTC. Aquat Microb Ecol 18:117-131

Simon M, Rosenstock B (1992) Carbon and nitrogen sources of planktonic bacteria in Lake Constance studied by the composition and isotope dilution of intracellular amino acids. Limnol Oceanogr 37:1496-1511

Smith JJ, McFeters GA (1997) Mechanism of INT (2-(4-iodophenyl)-3-(4-nitrophenyl)-5-phenyl tetrazolium chloride), and CTC (5-cyano-2,3-ditolyl tetrazolium chloride) reduction in Escherichia coli K-12. J Microbiol Methods 29: 161-175

Sommaruga R, Conde D (1997) Seasonal variability of metabolically active bacterioplankton in the euphotic zone of a hypertrophic lake. Aquat Microb Ecol 13:241-248

Sommaruga R, Krossbacher M, Salvenmoser W, Catalan J, Psenner R (1995) Presence of large-virus like particles in a eutrophic reservoir. Aquat Microb Ecol 9:305-308

Editorial responsibility: James Hollibaugh, Athens, Georgia, USA
Striquer-Soares F, Chevolot L (1996) Particulate and dissolved carbohydrates and proteins in Lobo Reservoir (São Paulo State Brazil): relationship with phytoplankton. J Plankton Res 18:521-537

Tabor PS, Neihof RA (1984) Direct determination of activities for microorganisms of Chesapeake Bay populations. Appl Environ Microbiol 48:1012-1019

Thom SM, Horobin RW, Seidler E, Barer MR (1993) Factors affecting the selection and use of tetrazolium salts as cytochemical indicators of microbial viability and activity. J Appl Bacteriol 74:433-443

Thouvenot A, Debroas D, Richardot M, Jugnia LB, Devaux J (2000) A study of changes between years in the structure of plankton communities in a newly-flooded reservoir. Arch Hydrobiol 149:131-152

Wright RT, Hobbie JE (1965) The uptake of organic solutes in lake water. Limnol Oceanogr 10:22-28

Zimmermann R, Iturriaga R, Becker-Birck J (1978) Simultaneous determination of the total number of aquatic bacteria and the number thereof involved in respiration. Appl Environ Microbiol 36:926-935

Zweifel UL, Hagström $\AA$ (1995) Total counts of marine bacteria include a large fraction of non nucleoid-containing bacteria (ghosts). Appl Environ Microbiol 61:2180-2185

Submitted: June 4, 2000; Accepted: August 29, 2000 Proofs received from author(s): September 27, 2000 